\title{
Study of the Mediating Role of Organizational Citizenship Behavior in the Relationship of Workplace Spirituality with Customer Loyalty and Service Quality in Saman Bank
}

\author{
Mohammad Hossein Kiyanzad ${ }^{1}$, Nader Sh. Kandelousi ${ }^{2}$ \& Soheila Sardar ${ }^{3}$ \\ ${ }^{1}$ MA scholar, public administration department, Islamic Azad University, Tehran Shomal branch, Tehran, Iran \\ ${ }^{2}$ Assistant proffesor, public administration department, Islamic Azad University, Tehran Shomal branch, Tehran, \\ Iran \\ ${ }^{3}$ Assistant proffesor, public administration department, Islamic Azad University, Tehran Shomal branch, Tehran, \\ Iran
}

Correspondence: Mohammad Hossein Kiyanzad, MA scholar, public administration department, Islamic Azad University, Tehran Shomal branch, Tehran, Iran.

Received: February 29, 2016

Accepted: March 22, $2016 \quad$ Online Published: June 22, 2016

doi:10.5539/mas.v10n8p243

URL: http://dx.doi.org/10.5539/mas.v10n8p243

\begin{abstract}
In today highly competitive banking industry, customer loyalty and customer satisfaction with banking services are among the important preconditions for survival and growth of banks. In this context, the relationship between customers and employees providing services is of significant importance and in general it can be said that frontline employees may attract customers and gain their satisfaction and loyalty by providing services beyond their role requirements. Present research aims to study the role played by workplace spirituality in organizational citizenship behavior, service quality and customer satisfaction. In present applied research, a survey methodology was employed and questionnaire copies were distributed to the sample derived from a statistical population comprising of all staff and customers of north Tehran branches of Saman Bank. Random stratified sampling procedure was used to obtain the appropriate sample for present study. As a result of it, 230 questionnaires (equal to the total number of employees) and 341 questionnaires (according to a sample based on Krejcie \& Morgan table with an estimated statistical population of 3000) were respectively distributed to employees and customers. Structural equation modelling (SEM) and LISREL software were used to study the relationships. Research findings confirmed all hypothesized relationships between the studied concepts.
\end{abstract}

Keywords: customer loyalty, perceived service quality, organizational citizenship behavior (OCB), workplace spirituality, structural equation modelling

\section{Introduction}

One of the most significant trends of business and management in 21st century actually appeared since mid-1990 is concentration on staff spirituality in organizations (Shellenbarger, 2000). Importance and volume of research literature in this field is increasing. Today many management journals have focused on workplace spirituality and it has found its way even to cover pages of such journals as Businessweek (Colin, 1999) and Fortune (Gunther, 2001). Also many books are published on this subject. In addition in 1999 Academy of Management formed its most recent specialized group named as "spirituality, religion and work" (SRW). Workplace spirituality is a new phenomenon which can be considered as a positive source of power in individual life because helping people to integrate their work and spiritual life may give meaning to an approximate number of 100000 hours of their work life and make the work more enjoyable, balanced and meaningful and cultivate their soul and spirit. Banks are among the institutions which have the most interaction with their clients and they may deal with hundreds of customers with different behaviors on a daily basis. On the other hand, increasing competition in banking industry is a threat to profitability of banks. One of the most significant subjects in this field is attraction of customer satisfaction. Thus banks need employees who perform beyond their role requirements and role specifications. These employees respect such values as ethics, honesty, integrity, conscience, generosity, trust, kindness and forgiveness in their organizational roles. One of the internal and natural aspects of human life is spirituality which influences organizational citizenship behavior (OCB). 
Respecting ethics and spirituality in banks may lead to appearance of behaviors beyond role requirements of employees and increased customer satisfaction and loyalty are among the major outcomes of it. Attachment is another outcome of workplace spirituality which may felt by the employees toward the organization and lead them to make more effort to achieve organizational goals.

Researchers believe that extra-role performance has a significant influence on organizational effectiveness. One of the most common cases of conceptualization and operationalization associated with extra-role behaviors is OCB (Bateman \& Organ, 1983; Organ, 1988).

Organizational citizenship behavior (OCB) has been the focus of many research works during recent 15 years and its significance continue to increase. Extant research works are mainly consisted of three groups. A group of these works are concentrated on prediction and empirical test of the antecedents of OCB. Various factors including job satisfaction, service quality, customer loyalty, organizational commitment, organizational identity, organizational equity, trust, leadership modes, relationship between leader and follower, etc. are proposed as antecedents of OCB (Podsakoff et al., 2000). On the other hand, another group of research works are concentrated on OCB. In this context, such factors as organizational performance, organizational effectiveness, organizational success, customer satisfaction, customer loyalty, social capital etc. are proposed (Bolino et al., 2002; Morrison, 1996; Podsakoff et al., 2000; Yoon \& Suh, 2000). Thus present paper seeks to study a relatively new concept i.e. workplace spirituality as the antecedent of OCB on one hand and evaluate the influence of OCB on two marketing variables including service quality and customer loyalty on the other hand. Thus the main question of present research is that whether workplace spirituality contribute to showing OCB by employees and whether showing OCB by employees enhances service quality and customer loyalty.

\section{Research Literature}

In present research, such variables as workplace spirituality, organizational citizenship behavior, service quality and customer loyalty are addressed. In the following these concepts are discussed.

\subsection{Workplace Spirituality}

Today it seems that employees demand more than material and monetary rewards wherever they work. They seek meaningful and inspiring jobs and want to balance their life. Workplace spirituality cover such concepts as sense of integrity and continuity at work and perception of deep values at work (Gibenz, 2000). Workplace spirituality is a framework of organizational values and implies a culture which increasingly lead employees beyond their typical work processes and improve their understanding on relationship with others and make them feel pleasure. (Beik Zad et al., 2011). Workplace spirituality refers to understanding and recognition of the fact that an aspect of employees' life is internal and intrinsic and it can be cultivated through conducting meaningful works in social life (Ashmos \& Duchon, 2000; Sheep, 2004). Workplace spirituality can be defined through four components: self-work immersion, meaning from work, self-actualization and personal growth in work life. Workplace spirituality includes individual efforts to find the final goal in his/her wok life, to have a strong relationship with his/her colleagues and other individuals associated with his/her work and to adapt his/her central beliefs to organizational values (Bradley \& Kauanui, 2003). Organizational spirituality at individual level may be considered as individual effort to find meaning and goal in his/her work life. At collective level, it refers to strong relationship between colleagues and those people contribute to their work. At organizational level. It means coordination between central beliefs and opinions and organizational values (Abedi Ja'fari \& Rastegar, 2007).

\subsection{Organizational Citizenship Behavior}

One of the definitions for organizational citizenship behavior (OCB) accepted by many scholars is presented by Organ (1988):" individual behavior that is discretionary, not directly or explicitly recognized by the formal reward system, and that in the aggregate promotes the effective functioning of the organization". The word discretionary shows that the behaviors do not cover those shown by individual to meet his/her needs or job specifications (Castro et al., 2004). According to another definition from Organ, OCB consists of those behaviors shown by employees with the aim of improving their performance effectiveness despite their personal productivity goals (Comeau et al., 2005).

Netemeyer classified $\mathrm{OCB}$ in four categories i.e. fairness and forgiveness, civil behaviors, altruism, conscientiousness and described them. Conscientiousness refers to those behaviors going beyond the requirements established by organization in workplace. For example, after hours work for organizational profitability. Altruism means helping colleagues to carry out their tasks. Some researchers combine conscientiousness and altruism and commonly consider them as helping behaviors (Mackenzie et al, 1993). 
However these behaviors are classified based on Organ's definition for OCB.

George and Brief (1992) argued that conscientiousness can be easily defined within the individual roles. They noted that focus on conscientiousness is indeed the focus on compliance to rules and regulations and in this way, it is a behavior within the pre-defined job roles. In spite of this, Bolino (1999) mentioned that it is necessary to seek new insights with respect to this concept in the future; an insight which show us the deep relations between OCB dimensions. For example, conscientiousness or altruism maybe exploited and adapted to influence management (Comeau et al, 2005). Finally, it should be said that the most significant dimensions attracted the researchers' attention include altruism, conscientiousness, courtesy, fairness and forgiveness and civil behavior. These five dimensions were proposed by Organ in 1988 and Podsakoff et al. (1990) generated standard measures for these dimensions using factor analysis and later these measures were used to assess OCB by many scholars (Podsakoff et al., 1990; Organ, 1988).

Altruism means helping other organizational members to deal with their problems and tasks. For example, some employees help new or low-skilled ones in doing their jobs. Conscientiousness refers to discretionary behaviors going beyond minimal role requirements. For example, an employee may stay in the workplace after work hour or spend little time on breaks. Courtesy includes employees' effort to avoid stresses and work problems in their relations with others. Fairness and forgiveness means showing patience and forgiveness in non-ideal organizational conditions without any complaint. Finally, civil behavior is defined as tendency to participate and take responsibility in organizational life and provide an appropriate image of the organization (Mackenzie et al., 1993; Podsakoff et al., 2000; Bell \& Menguc, 2002)

\subsection{Service Quality}

In management and marketing literature still there is not one single definition and conceptualization for service quality. However, perceived service quality may be considered as some judgement by customers based on their perceptions after the process of service reception and in this way they compare their expectations to the received services (Gronroos, 1984; Zeithaml, 1988).

According to this definition, service quality is dependent upon two factors: Expected services and perceived services. Gronroos (1984) argued that previous experiences on a service may influence the customer expectations; however, perceived service results from perception of customers about the actual service. Indeed service quality is a kind of attitude related to, but not equal to, customer satisfaction; it results from comparison of customers' expectations with organizational performance (Bolton \& Drew, 1991; Parasuraman et al., 1988).

It is said that quality is a multi-dimensional phenomenon; to realize service quality, its significant dimensions should be identified. According to the idea of the gap between expectations and perceptions, Parasuraman et al. (1988) identified five main dimensions of service quality and building upon to that, they developed a scale to assess service quality in 1988 known as SERVQUAL model. This model is globally of significant acceptance and used by various service industries including medical schools, hospitals, retailers and store chains, universities and higher education institutions, tourism institutions, banks, hotels, etc. Indeed, it is still the most common instrument to assess service quality. Dimensions of this model comprise of reliability, responsiveness, assurance, empathy and tangibles. In the following the dimensions are provided together with their definitions (Wang \& Sohl, 2003; Parasuraman et al., 1988).

1. Tangibles: This measure is associated with physical attractiveness of facilities, equipment and other items of service firms and appearance of service providers.

2. Reliability: This concept refers to reception of accurate services by customers at the first time without any mistake. Also it refers to timeliness of services.

3. Responsiveness: It means that personnel of the service organization tend to help customers, meet their demands, let them know when the required service is ready and provide quick service.

4. Assurance: It means that personnel behavior makes customers feel assured and secure about the organization. Also it means that personnel are usually polite and well-mannered and have adequate knowledge to answer customer questions.

5. Empathy: It Means that the service organization recognizes and understands customer problems, performs based on the best interest of them and is convenient to them with respect to its operating hours.

\subsection{Customer Loyalty}

In academic literature, there are many research work on definition and identification of customer loyalty dimensions (Dick \& Basu, 1994; Oliver, 1997; Rundle-Thiele, 2005). Simply speaking, customer loyalty may be 
defined as favorite attitude towards a brand or service and repetitive purchase of it (Dick \& Basu, 1994). Thus customer loyalty is realized when customers have favorite attitude towards a product or service and/or the organization providing it and repeatedly use that product or service (Wang \& Sohl, 2003).

In service context, loyalty is extensively defined as "observed behavior" (Bloemer et al., 1999). In explaining this definition, Tucker (1964) stated that one should not pay attention to the individual thought and neural mechanisms. But the brand loyalty is realized in the individual behavior. Jacoby (1971) also confirmed those studies which focused on behavioral outcomes not on customers' thoughts and opinions. Simply speaking, customer loyalty is measured based on outcome features. This implies measurement of purchase continuity, share of wallet and purchase profitability (Caruana, 2002).

However behavioral measures such as repeat purchase are criticized because of not having conceptual basis and their limited perspective (focus on outcome) on a dynamic process. For example, low repeat purchase rate for a certain service maybe a result of such situational factors as lack of accessibility, lack of service providers, etc. thus behavioral attitude towards loyalty is not able to provide a systematic and comprehensive insight related to basic reasons for loyalty. Instead, this attitude is based on customer preferences playing a significant role in loyalty. In addition, it is possible that repeat purchase even is not based on customer preferences, but it is based on various obstacles preventing customer switching behavior (Bloemer et al., 1999).

With respect to the above-said, customer loyalty is considered as an attitudinal construct. For example, this concept is appeared as recommendation to other potential customers. Finally, it should be said that another approach to customer loyalty was introduced in addition to attitudinal and behavioral approaches. This approach is cognitive one. Operationalized definition of this approach is often stated as the first product or service comes to individual mind while making purchase decision. Also Ostrowski, et al. (1993) defined it as the first product or service chosen by the individual among various products and services (Bloemer et al., 1999).

In the following and in Table 1, the studies are addressed which are in close association with the present research.

Table 1. Previous studies

\begin{tabular}{cc}
\hline Reference & Study Outlook \\
\hline (Mahdi Fattahi, 2006) & This study examined the influence of workplace spirituality on OCB and its
\end{tabular}

(Mahdi Fattahi, 2006) This study examined the influence of workplace spirituality on OCB and its relation with customer loyalty and service quality in Social Security Organization. It used Pearson test and structural equation modelling to study the relationship between variables. Research findings showed appropriate factor loadings and significant relationships between workplace spirituality dimensions and OCB.

(Kazem Pour et al., 2012) This study examined the influence of workplace spirituality dimensions on OCB among nurses with mediating role of emotional commitment. This study suggested that nurses' citizenship behavior led to improved performance of them. In this study it was hypothesized that the mediating variable of commitment increased with improvement in workplace spirituality and this led to appearance of OCB. Data collection was conducted using survey methodology and questionnaires distributed to 305 nurses in 305 Iranian public hospitals. Data analysis was conducted using Pearson correlation, simple regression and path analysis. Research results showed that spirituality dimensions including meaningful work, social feeling ad compatibility with organizational values had positive relationships with OCB.

(Naderian et al., 2011) The study title was "simple and complex relationships between spirituality and loyalty in workplace". It used correlation method. Statistical population of the study comprised of employees of Isfahan branch of one of the state ministries. Pearson correlation coefficient and stepwise regression were used for data analysis. Research findings also showed that all 11 components od spirituality had significant relationships with loyalty but neglecting growth and sublimation had negative relationship with loyalty.

(Farhangi et al., 2006) This study addressed spirituality in workplace and its role in improved OCB. The study examined the factors inducing OCB among Tehran University personnel ad investigated its relationship with spirituality. The study used 
exploratory factor analysis to identify the factors and then exploited structural equation modelling to examine the relationships. Research results showed a significant positive relationship between workplace spirituality and citizenship behavior.

(Ahmadi et al., 2011) The study titled "a model for study of general citizenship behavior, spirituality and OCB in Iranian public sector (case study of Iranian Insurance Company)" examined the relationship between general citizenship behavior and spirituality as independent variables and organizational citizenship behavior as dependent variable and three job attitudes i.e. participation in decision making, job satisfaction and organizational commitment as mediating variables in Iranian Insurance Company which is a business company providing services in public sector. Data analysis was conducted based on correlation analysis. Path analysis results showed that there was a significant relationship between both general citizenship and spirituality and job attitudes and organizational citizenship behavior including two dimensions of altruism and compliance. Despite the significant and sometimes surprising differences in details of the studied relationships, the main point of the study was the greater influence of spirituality on organizational citizenship behavior compared to general citizenship behaviors and this is not surprising with respect to the fact that the former is more established than the latter in the studied population.

(Nikpour et al., 2011) The study addressed the relationship between workplace spirituality and organizational citizenship behavior in Foundation of Martyrs and Veterans Affairs of Kerman city. The study was a descriptive-correlation one based on a survey methodology. Statistical population of the study comprised of all staff of Foundation of Martyrs and Veterans Affairs in 2010. Simple sampling technique was used to obtain a sample of 190 subjects. Inferential and descriptive statistics were used for data analysis. Data collection instruments for workplace spirituality was Milliman et al. scale and data on OCB was collected using an author-developed questionnaire. Research findings showed the significant relationship between meaningful work, interconnectedness and alignment with organizational values and OCB.

(Castro et al., 2000) The study examined the influence of staff OCB on customer loyalty. The study purpose was to investigate the influence of behaviors of employees in a service firm on customer understanding of service quality and in turn on corporate performance. The authors believed that OCB was truly recognized as employees' behavior but its role was not identified with respect to corporate profitability and understanding customers. Thus they examined the influence of OCB on customer loyalty and the mediating role of service quality with respect to the relationship between these two concepts. They studied two paths A and B in their study. The path A represented the relationship between OCB and customer loyalty and path B represented the relationship between OCB and service quality. The study used structural equating modelling for path analysis and the results for OCB path was 0.153 for standard error and 1.41 for significance level and no significant relationship was found.

\subsection{Relationship between Spirituality in Workplace and Organizational Citizenship Behavior}

Any researcher acknowledges that one of the most important components of OCB in organizations is presence of spirituality in workplace. According to Milliman et al. (2003) workplace spirituality represents employees' effort in workplace to find their final goal in order to create a strong connection with colleagues and other people in workplace. This entails connection between individual basic beliefs and organizational values. Researchers who studied the influence of workplace spirituality on organizational achievements showed that spirituality improved employees' honesty and integrity and resulted in their happiness and satisfaction (Krishnakumar \& Neck, 2002). Many researchers suggested that happy employees were more beneficial to the organization, respected others and tended to repeat their organizational citizenship behaviors (Avey, Wernsing \& Luthans, 2008; Miles, Borman, Spector \& Fox, 2002). In the present research, the first path is the relationship between workplace spirituality 
and OCB.

H1. There is a significant relationship between workplace spirituality and organizational citizenship behavior in Saman Bank.

\subsection{Relationship between Organizational Citizenship Behavior and Service Quality and Customer Loyalty}

OCB concept is related to identification, management and measurement of employees' behavior associated with improved organizational effectiveness and is overlooked in conventional methods of employee's performance evaluation. OCB definition is mostly associated with description of service employees' behavior. The first feature of OCB is its voluntary nature. Various aspects of services require showing discretionary behaviors by employees which may be critical to perceived service quality. Providing services include interpersonal interaction to a large extent. These interactions, either short or prolonged, result in development of relationships with customers or this may help employees to understand customer needs and adapt services to them based on this knowledge. Development of an accurate job description with respect to quality of interaction with customers is a difficult task. Though some behaviors may not be defined in a clear way (e.g., calling customers by their first names), there are some other behaviors which are associated with employees' attitudes and motivations (e.g., make customers happy). Thus in order to develop positive interactions, employees should engage in a set of behaviors which some of them cannot be defined as mandatory (Bienstock et al., 2003).

The second feature of CB is that it arises from individual independent intentions. Various dimensions of service quality including individual independent intentions contribute to the provided services and studies show that these type of activities influence customer satisfaction. Parasuraman (1988) provided five dimensions of service quality in SERVQUAL scale. Two of them (empathy and responsiveness) are associated with and describe employees' behaviors. But providing a complete description for these behaviors is a difficult job. For example, job description related to empathy may include listening to the customer but there are many different ways to achieve this goal some of them having more potential to satisfy customers. This is the case for responsiveness too. For example, employees may show various degrees of responsiveness and customers may be more satisfied with some of them. Bitner (1995) found that employee's effort has a positive influence on customer satisfaction.

Final feature of OCB is that this behavior contributes to organizational benefits. As a result of interacting with customers, employees may bring about various degrees of customer satisfaction and in turn organizational benefits. For example, an employee in insurance company may avoid selling excess products even if he/she feels that a customer may be ready to purchase more products and this clearly results in more organizational profitability. Even in some cases that the service is defective, employees' behavior may compensate for the defects. For example, experience of a bad dinner may be got over by a free appetizer (without the need for not paying the whole bill by customer) and results in customer satisfaction. These examples show that service employees should value customers' expectations and choose the best response to them. Service firms request their personnel to choose those behaviors and solutions which are in the best interests of the organization. In other words, they are requested to show organizational citizenship behavior. This shows that OCB may have positive influence on providing successful services and indeed it leads to providing services based on customer needs and finally entails positive perceived service quality (Hee Yoon et al., 2003).

If organizational citizenship behaviors contribute to employees' performance with respect to customers and lead to improved customer perception of service quality, then the significant question for service organization management is that how employees should be encouraged to show these behaviors. Graham (1991)'s organizational rights and responsibilities theoretical framework responds to this question. Id an organization want to encourage OCBs, then it should provide appropriate citizenship rights (to encourage compatibility), social rights (to encourage loyalty) and political rights (to encourage participation). Finally, it should be noted that OCB should provide an internal framework to enhance service quality through improving service performance based on organizational requirements or standards because developing such framework contributes to customer positive perception of service quality.

H2a. There is a significant relationship between organizational citizenship behavior ad service qualities in Saman Bank.

\subsection{Relationship between workplace spirituality and Customer loyalty}

There are many reasons for the relationship between OCB and customer loyalty. Based on studies about social networks, it can be said that when a customer is satisfied with his/her relationship with organizational staff, it is more likely to stay with the organization for a long time (Hansen et al., 2003). Therefore, employees' behaviors with respect to customers have major effects on customers' behaviors and intentions in relation to repeat 
purchasing of organizational products and services (Castro et al., 2004).

The second reason is associated with internal marketing view in service business. Based on internal marketing view, every behavior in service context has influence on customer perception of the services and customers become aware of service quality as a result of interaction with employees. Internal marketing view implies that in order to achieve successful interaction with customers, effective interactions should be present among employees and between employees and customers at first instance. Appropriate interactions between customers and employees is achieved only after realization of effective internal interactions (George, 1991; Kelley \& Hoffman, 1997) which leads to increased customer loyalty. Thus one studied path in present research may be considered as the relationship between OCB and customer loyalty.

H2b. there is a significant relationship between organizational citizenship behavior and customer loyalty in Saman Bank.

\subsection{Research Conceptual Model}

In present study, workplace spirituality was evaluated at individual, group and organizational levels using Milliman et al. (2003) scale. Organizational citizenship behavior was assessed via five dimensions of Organ (1998) model. Perceived service quality was measured using Parasuraman et al. (1988) model and the variable customer loyalty was examined using Dick et al. (1994)'s customer loyalty model.

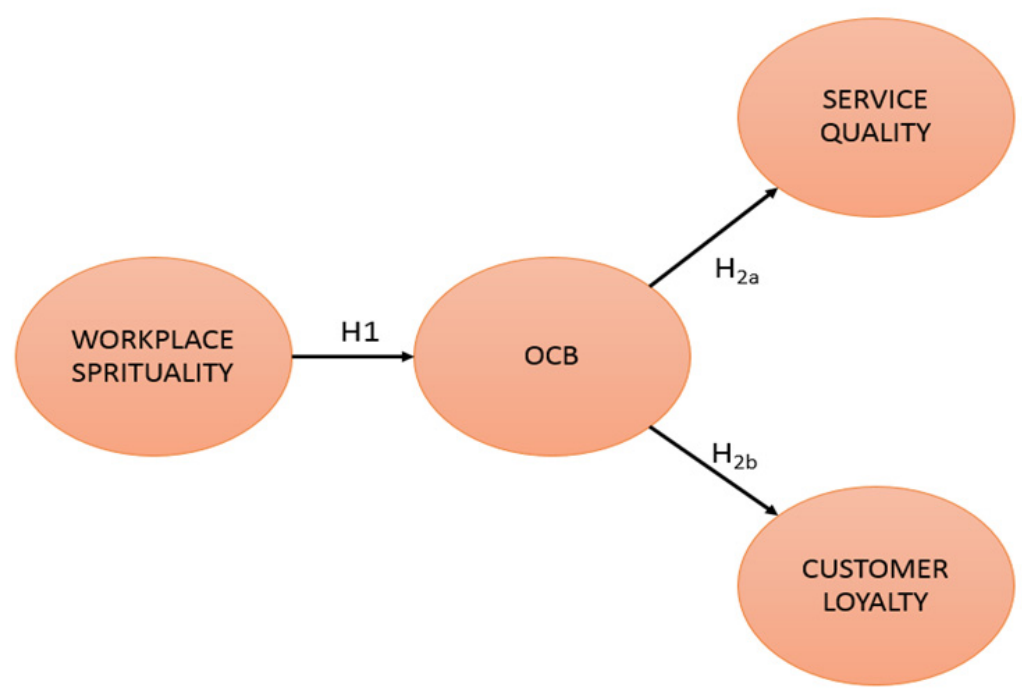

Figure 1. Research conceptual model

\section{Research Methodology}

Present applied research had a survey methodology and questionnaire copies were distributed to the sample derived from a statistical population comprising of all staff and customers of north Tehran branches of Saman Bank. Random stratified sampling procedure was used to obtain the appropriate sample for present study. As a result of it, 230 questionnaires (equal to the total number of employees) and 341 questionnaires (according to a sample based on Krejcie and Morgan table with an estimated statistical population of 3000) were respectively distributed to employees and customers. Structural equation modelling (SEM) and LISREL software were used to study the relationships.

\section{Research Findings}

In present study, structural equation modelling was used in two steps. In first step the relationship between workplace spirituality and organizational citizenship behavior was studied (on a sample of 230 subjects) and in the second step, organizational citizenship behavior, service quality and customer loyalty were examined (on a sample of 384 subjects). 


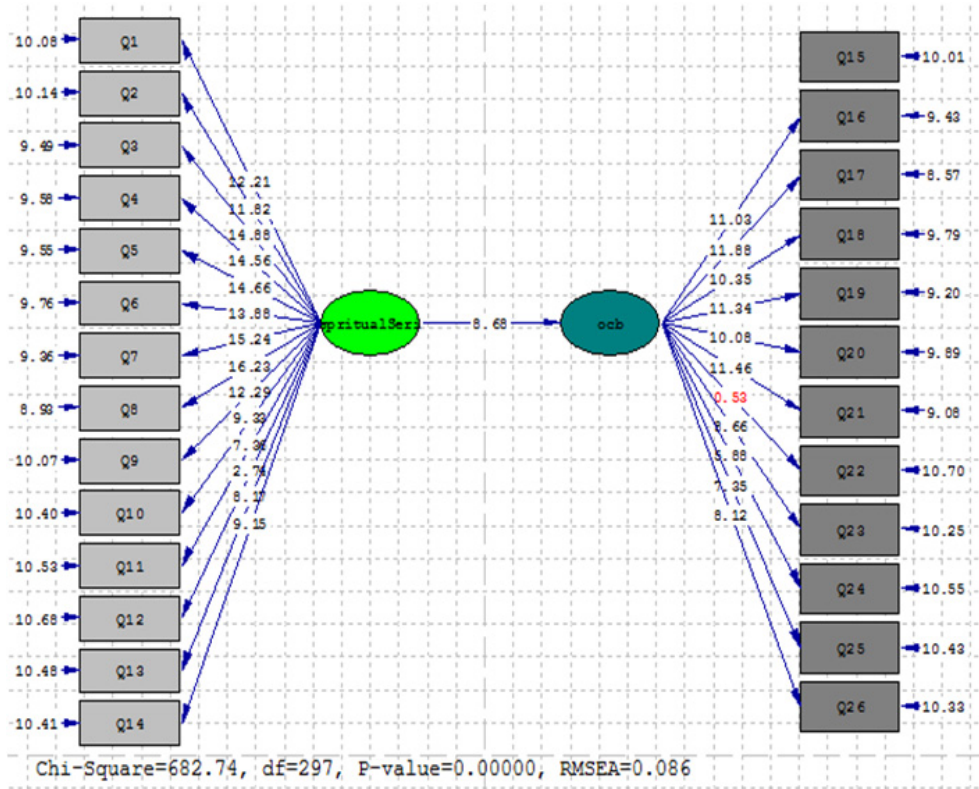

Figure 2. Output of the first step of the path analysis based on significance level (t-value)

Output of the first step of path analysis based on standard error

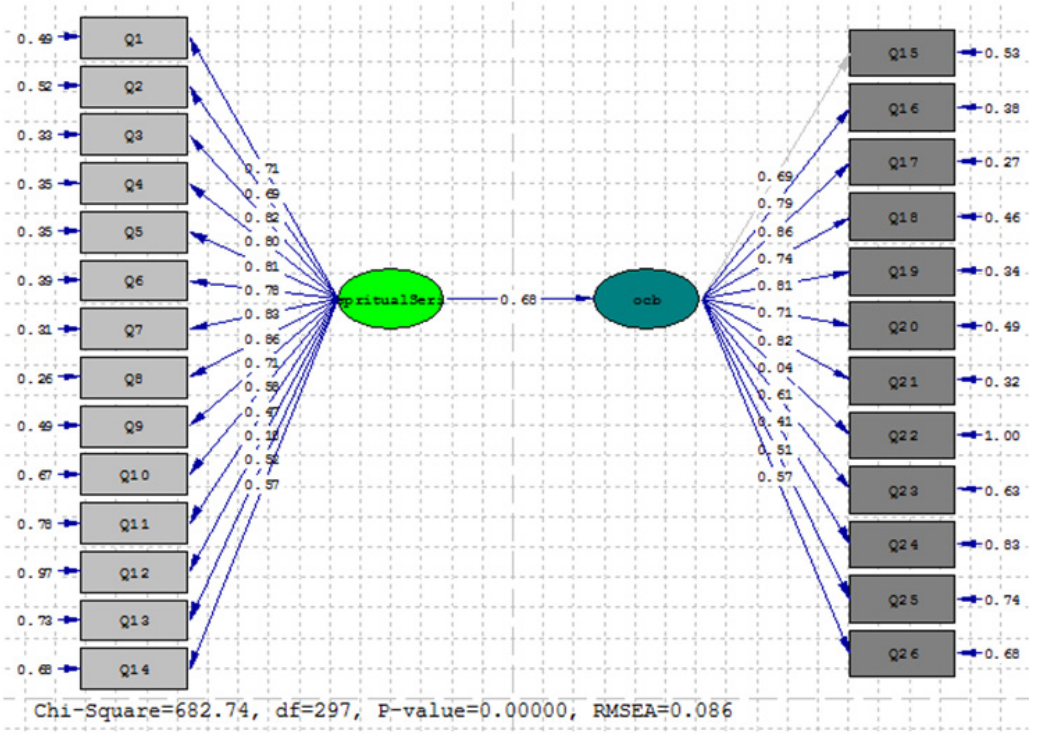

Figure 3. Output of the first step of the path analysis based on standard error (t-value)

Output of the second step of path analysis based on level of significance (t-value)

In this section, the second sample of the study comprising of 384 customers of Saman Bank was used to examine the second path from OCB to service quality and customer loyalty and model output is presented in Figure 3. 


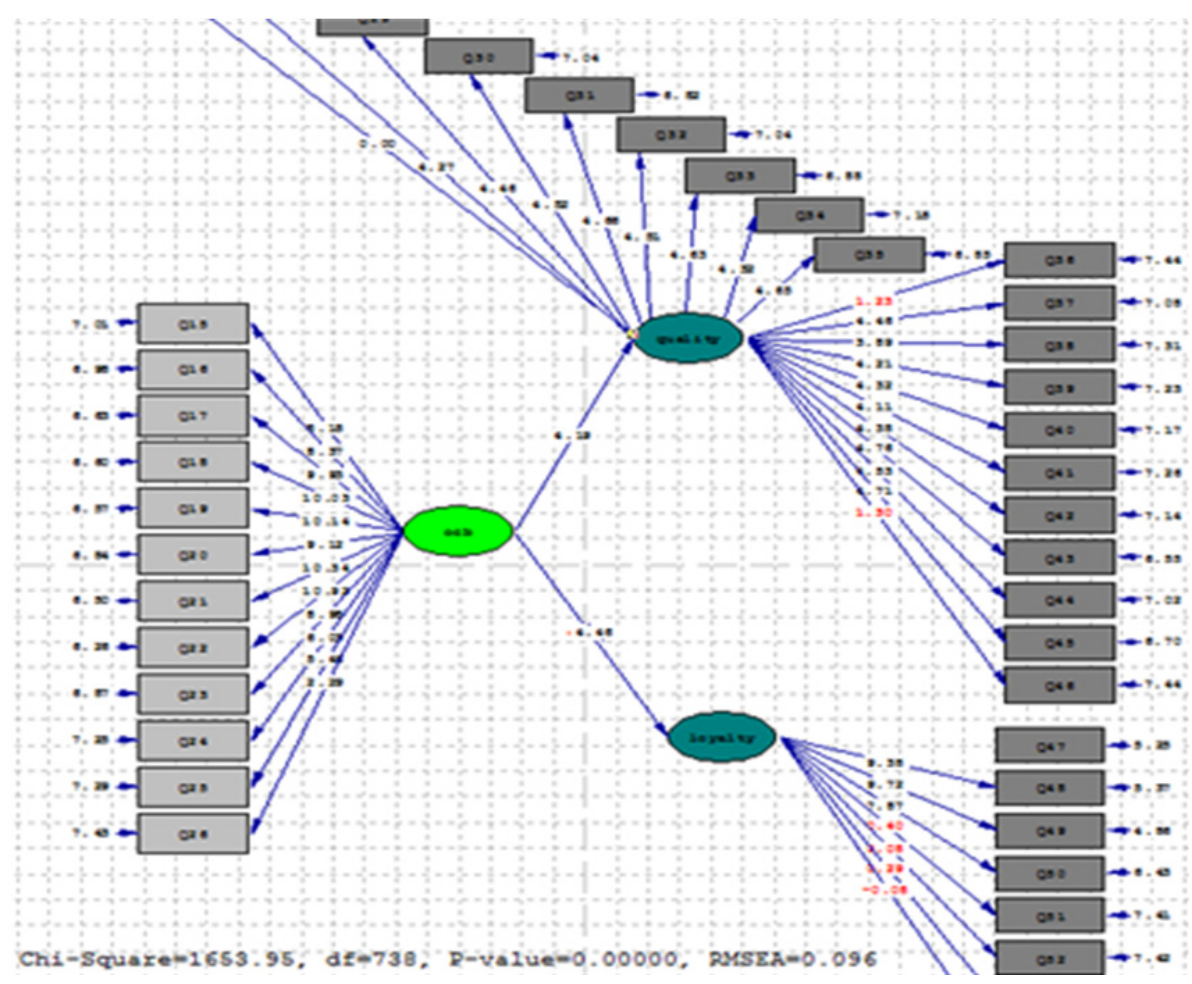

Figure 4. Output of the second step of path analysis based on significance level (t-value)

Output of the second step of path analysis based on standard error (t-value)

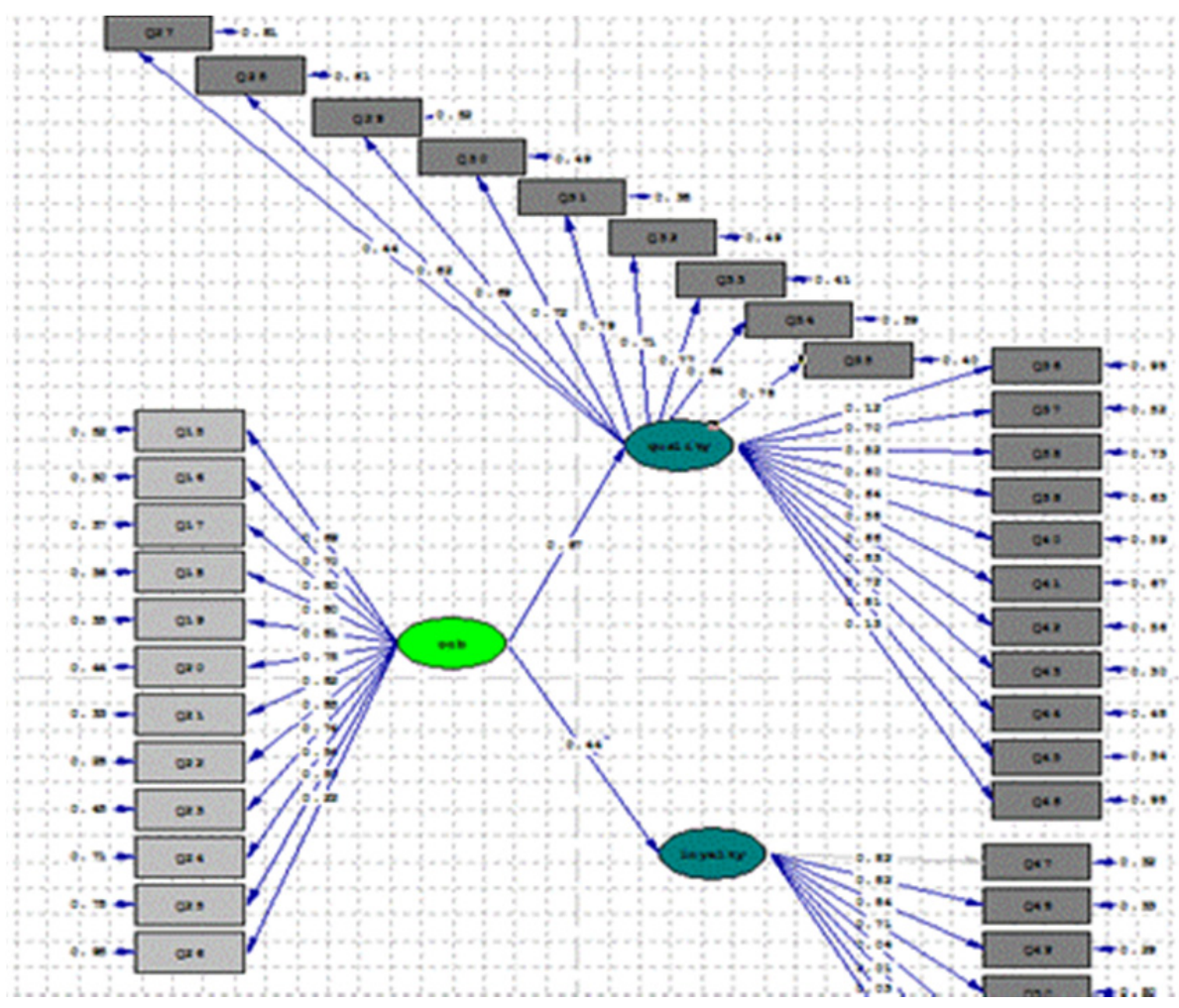

Figure 5. Output of the second step of path analysis based on significance level (t-value) 
Table 2. Results of test of research hypothesis based on structural modelling equation

\begin{tabular}{|c|c|c|c|c|c|}
\hline Hypothesis & & Path & & t-value & Result \\
\hline H1 & Workplace spirituality & $\begin{array}{l}\text { Organizational citizenship } \\
\text { behavior }\end{array}$ & & 8.68 & supported \\
\hline H2 & $\begin{array}{l}\text { Organizational citizenship } \\
\text { behavior }\end{array}$ & Service quality & & 4.19 & supported \\
\hline H3 & $\begin{array}{l}\text { Organizational citizenship } \\
\text { behavior }\end{array}$ & Customer loyalty & & 4.45 & supported \\
\hline \multirow[t]{2}{*}{ H4 } & Workplace spirituality & $\begin{array}{l}\text { Organizational citizenship } \\
\text { behavior }\end{array}$ & $\begin{array}{l}\text { Services } \\
\text { quality }\end{array}$ & 7.19 & supported \\
\hline & Workplace spirituality & $\begin{array}{l}\text { Organizational citizenship } \\
\text { behavior }\end{array}$ & $\begin{array}{l}\text { Customer } \\
\text { loyalty }\end{array}$ & 6.79 & supported \\
\hline
\end{tabular}

Also test of research hypotheses using structural equation modelling shows that software output suggests suitability of the fitted structural model for test of hypotheses $\left(\chi^{2} / \mathrm{df}\right.$ is below 3 ; thus $\chi^{2}$ value is appropriate. p-value is lower than 0.05 and RMSEA of 0.061 shows goodness of fit for structural model). In other words, observed data are compatible to conceptual model to a great extent.

Table 3. Fit indices of research structural equation models

\begin{tabular}{ll}
\hline Fit Index & Value \\
\hline $\mathrm{df}$ & 167 \\
$\chi^{2}$ & 431 \\
$\chi^{2} / \mathrm{df}$ & 2.07 \\
RMSEA & 0.025 \\
NFI & 0.87 \\
NNFI & 0.85 \\
CFI & 0.9 \\
GFI & 0.85 \\
AGFI & 0.84 \\
\hline
\end{tabular}

\section{Discussion and Conclusion}

As expected, there was a positive relationship between workplace spirituality and organizational citizenship behavior. This is a rational relationship. Presence of this it may be justified as following. We conceptualized workplace spirituality based on three dimensions including meaningful work, interconnectedness and alignment with organizational values. Employees who feel a deep meaning in their jobs, pay a great attention to their performance. These employees often have great conscientiousness and carry out their jobs in a spontaneous and self-managed way. For example, they observe rules and regulations even when no one monitors them. These employees try to do a better work and always update their information, knowledge and skills. Respecting the deep meaning these employees feel in their work, they tolerate difficult situations and also help their colleagues including low skilled ones in dealing with their tasks.

Naturally employees who believe that humans are connected together and feel a deep interconnectedness toward their colleagues in workplace, pay more attention to them. These employees help other members in doing their tasks. For example, one employee may help his/her colleague in dealing with a high work load due to his/her absence at workplace. These employees also tend to carry out works which are not within their job description because they like their organization. Such employees who believe in their interconnectedness with their managers and subordinates, have more conscientiousness and do not exaggerate minor problems. Instead of focusing on defects of organization and others' mistakes, they pay attention to positive aspects of work so that both improve the performance and make organizational atmosphere friendlier.

Employees who see their values and goals in alignment with organizational values and missions, believe that organization takes care of them and is sensitive to their problems. They perceive organizational atmosphere as positive and focus on improvement of their performance and enhance organizational image. These employees are very interested in participation and take responsibilities in organizational life. These employees contribute to organizational performance improvement by helping others enthusiastically in particular those who experience 
problems with their work. Probably these employees are able to work more than what is required based on their job description, have a high level of conscientiousness, have less complaint with respect to difficult work situations, and take actions to improve organizational image in the society. This is because they consider the organization as their supporter and do not consider themselves separate from the organization.

According to the above-mentioned, it can be concluded that employees who experience spirituality in the organization are more willing to do works beyond their job description (organizational citizenship behavior).

As expected, there was a positive relationship between organizational citizenship behavior and service quality. This is a rational relationship. Presence of this relationship may be justified as following. Organizational citizenship behavior has a positive influence on the relationship between employees and customers and improve customers' perceptions of service quality. Employees who show organizational citizenship behaviors are able to improve service quality because they try to help others including customers in the best possible way.

Social theory also helps in understanding of the above relationship. According to the research on socialization employees who show one of helping behaviors such as OCB are more likely to show other ones e.g., customer oriented behaviors. For instance, a conscientious employee is more likely to try towards solving customer problems.

The other reason is the influence of OCB on internal aspects of the organization which indirectly contributes to improved service quality. OCB increases employees' and work groups' productivity, encourage team work, enhance employees' communications, collaboration and helping behaviors, decreases error rates and improve organizational participation and involvement of employees. Employees who perceive work environment positively, are more likely to be customer-oriented. Therefore, OCB leads to improved quality of services provided by employees to customers through influencing organizational internal factors such as service atmosphere, work environment, protection of employees, etc. According to the all above-said, it can be concluded that if the internal atmosphere of the organization encourages OCB and behaviors beyond job description, service quality is improved.

Of course the author believes that there are some mediating and intervening variables which should be identified in future research. Contrary to our expectation, no significant relationship was found between OCB and customer loyalty. The reason may be that OCB and customer loyalty are two different variables because the former is an intra-organizational variable evaluated by employees or their supervisors but the latter is an extra-organizational variable evaluated by customers. This results in a situation in which the correlation between these two variables is influenced by many various factors. The author believes that many variables including mediating, control, intervening and other ones are influential in this field.

In the Iranian context, there are many semi-public and private banks in intensive competition to attract customers, thus making customers loyal to the organization is of significant importance. In this context when a customer is not satisfied with bank services, he/she easily switch to the bank rivals. However, this is not the case with respect to Social Security Organization. Suppose a customer who wants to use health insurance service and is not a member of any public organization. Thus the only choice of the customer is between using or not using the services provided by Social Security Organization and he/she is not able to use services from a rival because simply these rivals do not exist. Thus customer loyalty to these organizations may not be attributed to the factors as OCBs as is the case for semi-public or private organizations dealing with high competition.

Of course according to the author's view, if we control in terms of type of the organization and its specific environment particularly with respect to the competition, then the positive relationship between such inter-organizational factors as OCB and customer loyalty may be expected.

Another point is that service quality is an extra-organizational variable too. Thus why did we obtain a positive relationship between this variable and the intra-organizational factor of OCB?

The author believes that the number of organization rivals (stable or instable environment) has a smaller influence on service quality than on customer loyalty; thus in present research the organizational type not contributed to the different influence of OCB on service quality for organizations respectively dealing with high and low competition. Generally, customer loyalty is associated with customer staying with the organization. When the customer has no choice, staying with the organization is not so much associated with intra-organizational factors. But the perceived service quality is associated with customer evaluation of the quality of services provided by employees. Thus intra-organizational factors including employees' behaviors (either intra-or extra-role) has a direct influence on customer evaluation of service quality. This is the case in both public and private organizations with all types of environments. 


\section{References}

Abedi, J. H., \& Rastegar, A. A. (2007). Appearance of Spirituality in Organizations: Concepts, Definitions, Presuppositions, Conceptual model. Quarterly of Iranian Management Science, 2(5).

Ashmos, D. P., \& Duchon, D. (2000). Spirituality at Work: A Conceptualization and Measure. Journal of Management Inquiry. 9(2), 134-146.

Avey, J. B., Wernsing, T. S., \& Luthans, F. (2008). Can positive employees help positive organizational change? Impact of psychological capital and emotions on relevant attitudes and behaviors. Journal of Applied Behavioral Science, 44(1), 48-70.

Bateman, T. S., \& Organ, D. W. (1983). Job satisfaction and the good soldier: The relationship between affect and employee citizenship. Academy of Management Journal, 26, 587-595.

Beik, Z. J., Hamdollahi, M., \& Hamdollahi, K. (2011). Study of the Influence of Workplace Spirituality on Organizational Citizenship Behavior of Employees of Educational Organizations of Five Districts of Tabriz City. Quarterly of Educational Leadership and Management, 15(4).

Bradley, J., \& kauanui, S. K. (2003). Comparing Spirituality on Three Southern California College Campuses. Journal of Organizational Change Management. 16(4), 448-462.

Buttle, F. (1996). SERVQUAL: Review, critique, research agenda. Eur J Mark, 30(1), 8-32.

Castro, C. B., Armario, E. M., \& Ruiz, D. M. (2004). The influence of employee organizational citizenship behavior on customer loyalty. International Journal of Service Industry Management, 15(1), 27.

Comeau, D. J., \& Griffith, R. L. (2005). Structural interdependence, personality, and organizational citizenship behavior: An examination of person-environment interaction. Personnel Review, 34(3), 310.

Conlin, M. (1999, November 1). Religion in the workplace: The growing presence of spirituality in corporate America. Business Week, p. 150.

Farhangi, A. A., Fattahi, M., \& Vasegh, B. (2006). Organizational Culture Management, 13, 5-36.

George, J. M. (1992). Brief AP. Feeling good-doing good: A conceptual analysis of the mood at work-organizational spontaneity relationship. Appl Psychol, 112(2), 310-329.

Gibbons, P. (2000). Spirituality at work: Definitions, measures, assumptions, and validity claims. The academy of management annual meetings, Toronto.

Gronroos, C. (1984). A service quality model and its marketing implications. Europan Journal of Marketing, $13(4), 36-44$.

Gronross, C. (1985). Internal marketing: Theory and practice (pp. 41-7). In: Block TM, Upah GD, Zeithmal VA, editors. Services marketing in a changing environment. Chicago, IL: American Marketing Association.

Gronross, C. (1992). Service management: A management focus for service competition. In: Lovelock CH, editor. Managing services: Marketing, operations and human resources (2nd Ed.) (pp. 9-16). Englewood Cliffs, NJ: Prentice- Hall.

Gunther, M. (2001). God and business. Fortune, 144(1), 58-80.

Kelley, S. W., \& Hoffman, K. D. (1997). An investigation of positive affect, prosocial behaviors and service quality. $J$ Retailing, 73(3), 407-27.

MacKenzie, S. B., Podsakoff, P. M., \& Fetter, R., (1993). The impact of organizational citizenship behavior on evaluations of sales performance. Journal of Marketing, 57, 70-80.

MacKenzie, S. B., Posdakoff, P. M., \& Fetter, R. (1993, February). The impact of organizational citizenship behavior on evaluations of salesperson performance. Mark, 57, 70-80.

Miles, D. E., Borman, W, E., Spector, P. E., \& Fox, S. (2002). Building an integrative model of extra role work behaviors: A comparison counterproductive work behavior with organizational citizenship behavior. International Journal of Selection and Assessment, 10(1-2), 51-57.

Parasuraman, A., Zeithmal, V. A., \& Berry, L. L. (2012). SERVQUAL: A multiple-item scale for measuring consumer perceptions of service quality. Retailing

Paulin, M., Ferguson, R. J., \& Alvarez-Salazar, A. M. (1999). External effectiveness of service management: A study of business-to-business relationships in Mexico, Canada, and USA. Int J. Serv Ind Manage, 10(5), 409-29. 
Paulin, M., Ferguson, R. J., \& Payaud, M. (2000). Business effectiveness and professional service personnel: Relational or transactional managers. Eur. J. Mark, 34(3-4), 453-71.

Paulin, M., Perrien, J., Ferguson, R. J. (1997). Relational contract norms and the effectiveness of commercial banking. Int. J. Serv. Ind. Manage, 8(5), 435-52.

Podsakoff, P. M., MacKenzie, S. B., Paine, J. B. \& Bachrach, D. G. (2000). Organizational citizenship behaviors: A critical review of the theoretical and empirical literature and suggestions for future research. Journal of Management, 26(3), 513-563.

Posdakoff, P. M., Ahearne, M., \& MacKenzie, S. B. (1997). Organizational citizenship behavior and the quality of work group performance. J. Appl. Psychol, 82(2), 262-70.

Rayment. (2007). The Global SMP Fitness Framework: A guide for Leaders Exploring the Relevance of Spirituality in the Workplace. Management Decision, 45(2), 217-234.

Rust, R. T., Zahorik, A. J., Keiningham, T. L. (1995, April; 1988). Return on quality (ROQ): Making service quality financially accountable. J. Mark, 59, 58-70. 64(1), 12-40.

Sheep, M. L. (2004). Nailing Down Gossamer: A Valid Measure of the Person Organization Fit of Workplace Spirituality. Academy of Management. Best Conference Paper MSR.60. Smith, J. A. \& J. J.

Shellenbarger, S. (2000, December 27). More relaxed boomers, fewer workplace frills and other job trends. Wall Street Journal, p. B-1.

Zeithmal, V. A., Berry, L. L., Parasuraman, A. (1993). The nature and determinants of customer expectations of service. J. Acad. Mark Sci., 21(1), 1-12.

\section{Copyrights}

Copyright for this article is retained by the author(s), with first publication rights granted to the journal.

This is an open-access article distributed under the terms and conditions of the Creative Commons Attribution license (http://creativecommons.org/licenses/by/3.0/). 